\title{
Do recruiters select workers with different personality traits for different tasks? A discrete choice experiment
}

Citation for published version (APA):

Wehner, C., de Grip, A., \& Pfeifer, H. (2020). Do recruiters select workers with different personality traits for different tasks? A discrete choice experiment. ROA. ROA Research Memoranda No. 012 https://doi.org/10.26481/umaror.2020012

Document status and date:

Published: 17/12/2020

DOI:

10.26481/umaror.2020012

Document Version:

Publisher's PDF, also known as Version of record

\section{Please check the document version of this publication:}

- A submitted manuscript is the version of the article upon submission and before peer-review. There can be important differences between the submitted version and the official published version of record.

People interested in the research are advised to contact the author for the final version of the publication, or visit the DOI to the publisher's website.

- The final author version and the galley proof are versions of the publication after peer review.

- The final published version features the final layout of the paper including the volume, issue and page numbers.

Link to publication

\footnotetext{
General rights rights.

- You may freely distribute the URL identifying the publication in the public portal. please follow below link for the End User Agreement:

www.umlib.nl/taverne-license

Take down policy

If you believe that this document breaches copyright please contact us at:

repository@maastrichtuniversity.nl

providing details and we will investigate your claim.
}

Copyright and moral rights for the publications made accessible in the public portal are retained by the authors and/or other copyright owners and it is a condition of accessing publications that users recognise and abide by the legal requirements associated with these

- Users may download and print one copy of any publication from the public portal for the purpose of private study or research.

- You may not further distribute the material or use it for any profit-making activity or commercial gain

If the publication is distributed under the terms of Article $25 \mathrm{fa}$ of the Dutch Copyright Act, indicated by the "Taverne" license above, 


\section{Maastricht University ROA}

Do recruiters select workers with different personality traits for different tasks?

A discrete choice experiment

Caroline Wehner

Andries de Grip

Harald Pfeifer

\section{ROA Research Memorandum}

ROA-RM-2020/12

Researchcentrum voor Onderwijs en Arbeidsmarkt | ROA Research Centre for Education and the Labour Market / ROA 


\title{
Do recruiters select workers with different personality traits for different tasks? A discrete choice experiment
}

\author{
Caroline Wehner \\ Andries de Grip \\ Harald Pfeifer \\ ROA-RM-2020/12 \\ December 2020
}

Research Centre for Education and the Labour Market Maastricht University

P.O. Box 616, 6200 MD Maastricht, The Netherlands

$\mathrm{T}+31433883647 \mathrm{~F}+31433884914$

secretary-roa-sbe@maastrichtuniversity.nl

www.roa.nl 


\section{Abstract \\ Do recruiters select workers with different personality traits for different tasks? A discrete choice experiment*}

This paper explores whether firms recruit workers with different personality traits for different tasks. For our analysis, we used data from a discrete choice experiment conducted among recruiters of 634 firms in Germany. Recruiters were asked to choose between job applicants who differed in seven aspects: professional competence, the 'big five' personality traits and the prospective wage level. We found that all personality traits affect the hiring probability of the job applicant; among them, conscientiousness and agreeableness have the strongest effects. However, recruiters' preferences differed for different job tasks. For analytical tasks, recruiters prefer more open and conscientious applicants, whereas they favour more open, extraverted, and agreeable workers for interactive tasks.

JEL classification: J23, D91, M51

Keywords: recruitment, personality traits, tasks, discrete choice experiment

Caroline Wehner

Federal Institute for Vocational Education

and Training

Robert-Schuman-Platz 3

D-53175 Bonn

Germany

wehner@bibb.de

and IZA, Maastricht University, UNU-Merit

Harald Pfeifer

Federal Institute for Vocational Education

and Training

Robert-Schuman-Platz 3

D-53175 Bonn

Germany

harald.pfeifer@bibb.de

and ROA
Andries de Grip

Maastricht University

ROA

P.O. Box 616

NL-6200 MD Maastricht

The Netherlands

a.degrip@maastrichtuniversity.nl

and IZA

\footnotetext{
* We thank Hans Heijke, Bart de Koning, Mark Levels, Samuel Mühlemann and the participants of the IAB Conference on Labour Market Transitions and of the CEDEFOP, EUROFOUND and IZA Conference on Workplace and Management Practices in 2020 for helpful comments.
} 


\section{Introduction}

Different tasks require different skills. This principle holds for vocational skills (Geel et al., 2011), but does it also apply to non-cognitive skills, such as different personality traits? The literature shows that personality traits correlate with the occupation and career choices of individuals (e.g. Jackson, 2006; Caliendo et al., 2014; Wells et al., 2016). However, occupations are characterised by various job tasks, and the within-occupation variance of tasks explains a significant portion of wage differentials between workers (Autor and Handel, 2013). This raises the question of whether different tasks require different personality traits in order to be carried out successfully. While the economic literature on job tasks as well as on personality has been thriving in the past decade, yet little is known about their interrelation. Except for a few studies (e.g. Mount et al., 1998), research has been rather silent about which tasks require which personality traits.

In this study, we explore whether firms recruit workers with different personality traits for different tasks. We conducted a discrete choice experiment among recruiters in 634 firms in Germany that hire skilled workers. ${ }^{1}$ Recruiters were asked to choose between job applicants who differed in seven aspects: professional competence, the 'big five' personality traits (openness to experience, conscientiousness, extraversion, agreeableness and emotional stability, see Borghans et al., 2008; Almlund et al., 2011) and the wage demanded by the applicant. In addition, we distinguished between analytical, routine, non-routine and interactive job tasks (Alda, 2014; Gerhards et al., 2014).

The advantage of using a discrete choice experiment for our analysis is that we do not depend on observed matching outcomes, where employers and employees' choices are determined simultaneously (Eriksson and Kristensen, 2014). Instead, the discrete choice experiment provides an experimental setting that is superior to observed outcomes because (1) all available choice options are observed, including the options that are not chosen; and (2) job attributes vary exogenously, which is not observed in naturally occurring data on recruitment. Each recruiter faces several choice sets of applicants. Therefore, we estimate mixed logit models that treat an individual's choices as dependent observations by allowing preference parameters to differ among individuals.

\footnotetext{
${ }^{1}$ We define skilled workers as those who have successfully completed an apprenticeship training.
} 
In line with our expectations, we found that all 'big five' personality traits affect the probability of the job applicant being hired; among these, conscientiousness and agreeableness have the strongest positive effects, whereas openness to experience, conscientiousness, agreeableness and emotional stability are valued more than having above-average professional competencies. However, the relevance of various personality traits strongly differs between the job tasks for which the firm recruits skilled workers: for analytical tasks, recruiters prefer more open and conscientious applicants, whereas they favour openness, extraversion and agreeableness for interactive tasks.

Our paper contributes to two strands of the literature. First, we complement the literature on non-cognitive skills and personality traits (e.g. Borghans et al., 2008) by analysing the importance of personality traits in the firm's hiring process. Second, we contribute to the literature on recruiters' hiring choices by relating employers' demands for workers with different job tasks and non-cognitive skills. Whereas the current literature focusses on other non-cognitive and cognitive skills (e.g. Weinberger, 2014; Piopiunik et al., 2020) and observable signals, such as grades or job experience, (Di Stasio, 2014), to our knowledge, the task-personality relationship has not been previously discussed.

In this paper, Section 2 discusses the literature on which the discrete choice experiment builds. In Section 3, we discuss the methodology of our experiments, the measurement of the attributes of the hypothetical job applicants, among which their personality traits, as well as the various job tasks we distinguish and the data we use. Sections 4 and 5 describe the estimation method and results, respectively. Section 6 is the conclusion.

\section{Literature}

While the literature shows that personality traits are important determinants for individuals' occupation and career choices (Jackson, 2006, Caliendo et al., 2014; Wells et al., 2016), they may also be relevant to the hiring decisions made by firms. Several studies have investigated the relevance of personality traits to recruiters' hiring choices. Dunn et al. (1995) analysed US managers' preferences regarding workers' 'big five' personality traits and general mental ability, showing that conscientiousness and general mental ability are the most important qualities for being hired. Hoeschler and Backes-Gellner (2018) focussed on the relative importance of the 'big five' personality traits as well as on grit, economic preferences (i.e. risk aversion and time 
preferences), marks and intelligence in the recruitment of former apprentices. They found that the 'big five' personality traits are the most important predictors for receiving a job offer at the end of the training period. Moy and Lam (2004) explored employers' hiring preferences in Hong Kong by referring to the 'big five' personality traits but also to practical skills. They showed that conscientiousness is the most dominant attribute in hiring decisions, followed by communication skills, openness to new experiences, academic performance and agreeableness.

A few studies on hiring preferences build on discrete choice experiments. Humburg and van der Velden (2015) studied the recruitment of Dutch university graduates and distinguished between interview selection and hiring. While for interview selection employers focus on elements appearing on CVs (i.e. degree, field of study, grades, work experience and study abroad), the hiring decision then depends on observable professional and social skills (i.e. general academic, creative, interpersonal, commercial, and entrepreneurial skills). Employers highly regard CV attributes such as relevant work experience and a good match between the field of study and the prospective role, and they value professional expertise and interpersonal skills more. Other discrete choice experimental studies have analysed the importance of the applicants' educational background (Teijeiro et al., 2013; Di Stasio, 2014; Di Stasio and van de Werfhorst, 2016), study abroad experiences (Petzold, 2017) or origin (Protsch and Solga, 2017) in the firm's hiring process. Moreover, some studies have focussed on specific sectors such as health institutions or high-tech firms (Biesma et al., 2007; Frosch et al., 2015).

The task-based approach (Autor et al., 2003) and subsequent empirical studies for Germany (e.g. Spitz-Oener, 2006) highlight the importance of tasks in determining the productivity and wages of a worker. Mount et al. (1998) show that agreeableness, in particular, is positively related to performance in jobs involving interpersonal interactions, suggesting that recruiters' choices may strongly depend on the tasks that the worker is hired for. However, to our knowledge, the heterogeneity of recruiters' hiring preferences regarding an applicant's 'big five' personality and job tasks is yet to be analysed.

\section{Methodology}

\subsection{Discrete Choice Experiment}

Assessing causal relationships in firms' recruitment decisions with standard surveys is challenging for two reasons: first, the attributes of both the hired applicant and the rejected 
competitors are typically not observed simultaneously; second, applicants' attributes are not exogenous, and it is difficult to create data that allows for identification strategies suited for causal inference (Eriksson and Kristensen, 2014). A discrete choice experiment provides an experimental setting, which is superior to standard survey questions. Hainmüller et al. (2015) show that experimentally elicited stated preferences are close to revealed preferences when the experimental design forces participants to make trade-offs.

We developed a randomised discrete choice experiment among a sample of firms' recruiters who hire skilled workers. This allowed us to randomly vary the attributes of all the job applicants. In the discrete choice experiment, the recruiters had to choose between two hypothetical job applicants and make such a decision in seven choice sets. ${ }^{2}$ Each job applicant is described by seven attributes including professional competence, personality traits and demanded wage level. In the vignette, it is mentioned that these applicant characteristics have been assessed by the candidates' CV, a job interview, and a trial working day. This suggests that our discrete choice experiment focusses on an already advanced stage in the application process, for which the recruiter invites only two applicants among all applications received. Based on a detailed final interview and a trial working day, the recruiter is then able to assess the competencies and personality of these applicants to make a final decision. Figure 1 provides an example of the choice set-up as seen by the interview partner on the screen during the interview. The decision-makers' choices allowed us to assess their preferences for applicants' attributes.

\section{[FIGURE 1]}

As Hainmüller et al. (2015) argued, a discrete choice experiment yields valid results if, in the case of our experiment, respondents possess a high level of recruitment experience and are regularly involved in the recruitment process. Therefore, we limited our working sample to firm owners, CEOs or heads of HR departments who were all dedicated to recruitment tasks and were familiar with making the relevant considerations in hiring new employees. In a survey that included the discrete choice experiment, we gathered information about the choices these recruiters made.

\footnotetext{
2 To create efficient choice designs, we make use of the user-written STATA module by Hole (2015).
} 


\subsection{Data}

Both the discrete choice experiment and the survey questions about the skilled workers' job tasks and the respondents' role in the recruitment of the firm were assessed as part of the BIBB Cost-Benefit Survey (BIBB-CBS) 2017/2018 (Schönfeld et al., 2020). The BIBB-CBS is a firm-level survey that is conducted every five years; it focuses on topics such as apprenticeship training, continuing training and the recruitment of workers from the labour market. The fieldwork was provided by infas (Institute for Applied Social Sciences, Bonn) using a personal interviewing method (CAPI). We sampled the firm addresses from a register of the Federal Employment Agency, which comprises all firms employing at least one worker subject to social security payments and thus is a representative source for our sample. During the interview, we randomly assigned a subset of firms to the discrete choice experiment.

To narrow down the set of respondents to the 'real' decision-makers, we inquired about the respondents' role in recruitment with the following: 'Please indicate the extent to which you participate in the decision-making and whether and which skilled workers are recruited'. The answer categories were: 'I decide on my own', 'I decide together with others', 'I support or advise the decision-makers', 'I am not involved in the decision', 'refused', and 'don't know'. For our analysis, we only used respondents with a strong participation in the recruitment decision - i.e. recruiters who decided independently or together with others. ${ }^{3}$ Additionally, we limited our working sample to respondents with valid information on the tasks performed during the latest recruitment process in the firm.

885 of the 983 recruiters participated in the discrete choice experiment $(90 \%),{ }^{4}$ of which 634 provided information about the job tasks that they were particularly interested in (72\%). Among those 634 recruiters, 541 made all seven choices, 24 made six choices, 21 made five choices, 14 respondents made four choices, 18 respondents made three choices, nine respondents made two choices and seven respondents made only one choice. This left us with data on 8,342 worker profiles from 4,171 recruitment decisions made by 634 respondents. Table A1 provides an overview about the proportional frequencies of the attribute values in the 8,342 worker profiles and the 4,171 attribute choices made by the recruiters.

\footnotetext{
${ }^{3}$ As a robustness check, we also included the respondents who only supported or advised the decision-makers. The estimation results of these regressions are similar to our main results and available from the authors upon request.

${ }^{4}$ In detail, 41 recruiters refused to participate before entering the discrete choice experiment. 57 recruiters entered the discrete choice experiment but did not make a recruitment decision.
} 
Table 1 gives an overview of the sample characteristics. The table shows that $62 \%$ of the recruiters are male and that the largest group of $46 \%$ has an academic degree, followed by $38 \%$ with a higher vocational degree and $16 \%$ with a vocational degree. The average firm tenure of the recruiters is 14 years. $41 \%$ of the respondents are firm owners, $17 \%$ CEOs, $10 \%$ department heads, $15 \%$ HR heads, $8 \%$ heads of commerce, $3 \%$ heads of training and $7 \%$ have other positions.

Table A2 compares the occupation and firm characteristics of our sample with those of the full sample of the BIBB-CBS. Although there are some differences in the composition of the respondents of both samples, the table shows that the required task structure is balanced in both samples, which is most important for the representativeness of our results.

\subsection{Job Applicants' Attributes and Attribute Values}

The job applicants in our discrete choice experiment differed in the following attributes: (1) professional competence, (2) personality traits and (3) gross wage the firm had to pay relative to the average wage of skilled workers in the company. An overview of all attributes and attribute values is provided in Table 2. We have designed the attributes and the attribute values in such a way that they realistically reflect the current recruitment situation. In the vignette, it is mentioned that these applicant characteristics have been assessed by their CV, and with a job interview and a trial working day. The attribute values of applicants' competences are either average (1) or above average (2). ${ }^{5}$ In our discrete choice experiment, personality is operationalised based on the 'big five' personality traits, which include openness to experience, conscientiousness, extraversion, agreeableness and emotional stability. ${ }^{6}$ The attribute values of personality traits are all based on characteristics used in the German Socio-Economic Panel (SOEP) (Richter et al., 2013, p.44-46). We additionally provided two opposing characteristics per personality trait using

\footnotetext{
${ }^{5}$ Under the assumption that competencies can be modelled on a continuous variable (from low to high), we did not need to rely on modelling the full scale of competencies. Due to vignette efficiency reasons, we used the average and high competency level to assess the relative importance of this attribute. Furthermore, the discrete choice experiment took place at the second stage of the hiring process, and the recruiters had already selected applicants with at least average professional competencies.

${ }^{6}$ For a detailed discussion see Matthews et al. (2012). The order of the 'big five' personality traits does not vary randomly but is presented according to the name 'OCEAN traits', which refers to the initial letters of the 'big five' and is typically used in psychological studies (Borghans et al., 2008). According to these studies, there are no inconsistent combinations of personality traits. Therefore, we allow for all personality trait combinations in a vignette.
} 
characteristics from the Big Five Inventory (BFI) (John et al., 1991) or the Ten-Item Personality Inventory (TIPI) (Gosling et al., 2003). ${ }^{7}$ We framed the items as follows:

Openness to experience

1. ... shows little imagination (BFI, SOEP, [reverse]) and solves tasks in a conventional way (TIPI).

2. ... shows active imagination (BFI, SOEP) and solves tasks in an original way (BFI, SOEP).

\section{Conscientiousness}

1. ... completes tasks carelessly (BFI) and unorganised (BFI).

2. ... completes tasks thoroughly (BFI, SOEP) and efficiently (BFI, SOEP).

\section{Extraversion}

1. ... seems to be reserved (BFI, SOEP) and quiet (BFI) when dealing with others.

2. ... seems to be communicative (SOEP) and sociable (BFI, SOEP) when dealing with others.

Agreeableness

1. ... seems to be cold ( $\mathrm{BFI}$ ) and sometimes somewhat rude to others (SOEP, BFI).

2. ... seems to be considerate (SOEP, BFI) and kind to others (SOEP, BFI).

Emotional Stability

1. ... seems to be tense (BFI) and nervous (SOEP, BFI).

2. ... seems to be relaxed (SOEP, BFI) and to handle stress well (SOEP, BFI).

With respect to the wage level demanded in the discrete choice experiment, we distinguished between a gross wage equal to the firm's average gross wage for skilled workers in the occupation and a wage that deviates from the average gross wage by $-15 \%,-10 \%,-5 \%,+5 \%,+10 \%,+15 \%{ }^{8}$

\section{[TABLE 2]}

\subsection{Measurement of Job Tasks}

We measured four different job tasks provided by the BIBB/BAuA Employment Survey (Alda, 2014) and the BIBB Qualification Panel (Gerhards et al., 2014): analytical, routine, non-routine and interactive tasks. Respondents answered the following question: 'How often does it occur in

\footnotetext{
${ }^{7}$ Because our aim was to relate as closely as possible to the validated items used in previous surveys, we refrained from formulating and implementing a third (i.e. middle or average) category for our 'big five' attributes.

8 We used deviations from the average wage instead of monetary values as wages in various occupations varied widely.
} 
a working situation that the last hired skilled worker in the selected profession (show selected occupation) ...

- ...must face new challenges that require intense up-front thinking (analytical tasks).

- ...must convince others or negotiate compromises with customers and colleagues (interactive tasks).

- ...must repeat work steps that are characterised by the same exact procedure (routine tasks).

- ...must react to and solve problems (non-routine tasks)'.

The answer categories vary from 1 (never) to 5 (often). Answer categories 7 and 8 are (reject) and (don't know).

\section{Econometric Model}

We analyse the choices made in our experiment within a utility maximisation framework using a mixed logit model explained by Revelt and Train (1998), Greene (2003) or Hensher and Greene (2003). The recruiters $(n=1, \ldots, N)$ must choose among $J$ job applicants in each of $T$ choice sets. The utility the recruiter $n$ obtains from job applicant $j$ in choice set $t$ is:

$$
U_{n j t}=\beta_{n X} X_{n j t}+\varepsilon n j t
$$

$X_{n j t}$ is a vector of observed explanatory variables including the attribute values of the job applicants as well as tasks measured in the survey and interacting with the attribute values. The coefficient vector $\beta_{n}$ is unobserved for each recruiter $n$ and assumed to be normally distributed with $f(\beta \mid \Theta)$, where $\Theta$ refers to the mean and the covariance of $\beta$. $\varepsilon_{n j t}$ is an unobserved random term, independent and identically distributed (IID) (McFadden, 1973) over recruiters $N$, job applicants $J$ and choice sets $T$. We calculate 300 Halton draws to approximate the log-likelihood function (Lancsar et al., 2017).

Recruiter $n$ chooses job applicant $j$, who provides the highest utility from a choice set $t$. Therefore, the probability that choice $j=1$ is:

$$
\operatorname{Prob}\left(U_{n} 1_{t}>U_{n} 2_{t}\right)
$$

In the conditional logit model, which is an alternative method to analyse discrete choice data (McFadden, 1973), $\beta$ is assumed to be the same for all recruiters. In contrast, the mixed logit 
model allows the recruiters' preferences for particular attribute values to vary. Thereby, we estimate both the mean coefficient $\beta_{i}$ and the standard deviation $\sigma$ of the mean coefficient for the so-called random variables, which maximise this probability using simulated maximum likelihood. As each respondent made up to seven recruitment decisions, we do not rely on independent observations. To target this issue, we calculate individual clustered standard errors.

\section{Results}

\subsection{Preferences for Applicants' Competence and Personality}

Table A3 shows the coefficients of the discrete choice experiment based on conditional and mixed logit regression models. The estimation results show that above-average professional competence as well as all five personality traits positively influence the probability of the job applicant being hired in both the conditional and the mixed logit model (Column 1 and 2). However, Column 3 shows that the standard deviations of the coefficients for professional competence and most personality traits are significant, which indicates that recruiters' preferences for these personal attributes are heterogeneous. This means that a mixed logit model is appropriate to analyse our data (see Cameron and Trivedi, 2010, p. 525); therefore, we will focus on the mixed logit results.

\section{[FIGURE 2]}

Figure 2 presents the marginal effects for professional competence and personality traits. It shows that recruiters favour agreeableness and conscientiousness, followed by emotional stability, openness to experience and extraversion - being more agreeable or conscientious increases the hiring probability by about 19 percentage points in comparison to less agreeable and less conscientious applicants. The respective effects of having a higher emotional stability or openness to experience are eight and seven percentage points in comparison to less emotionally stable or less open applicants. Being more extraverted increases the probability of being hired by a firm by merely two percentage points in comparison to less extraverted applicants. 
In terms of predicted probabilities, an applicant who is less agreeable, for example, has a $37 \%$ probability of being hired, while someone who is more agreeable has a $56 \%$ probability. ${ }^{9}$ These findings show that our results are economically meaningful; therefore, the applicant's personality plays an important role in the individual hiring probability.

This result is in line with related studies having found that particularly applicants' conscientiousness is a relevant hiring signal for managers (Dunn et al., 1995; Moy and Lam, 2004; Hoeschler and Backes-Gellner, 2018), followed by agreeableness, openness to experience and emotional stability, while extraversion is less important for job offers (Hoeschler and BackesGellner, 2018).

Above average professional competence increases the hiring probability by four percentage points. This finding is in accordance with Humburg and van der Velden (2015), who showed that recruiters generally have a tendency to avoid applicants with below-average professional competencies but do not have a particular preference for those with above-average ones.

Looking at the wage attributes included as wage claim dummies, Table A3 suggests that recruiters prefer the average wage, and that wage claims above and below the average wage in the firm are significantly less preferred by recruiters. This result is partly in line with the findings by Humburg and van der Velden (2015); however, in our analysis this preference for the average wage is even more pronounced. ${ }^{10}$

\subsection{Heterogeneity in Personality Preferences by Job Tasks}

Table A4 shows the interaction effect between the applicant's attributes for professional competence as well as personality traits and analytical, non-routine, routine and interactive job tasks elicited in the firm-level survey. Column 1 shows that, for analytical tasks, recruiters prefer applicants with a high openness to experience and conscientiousness. For tasks that focus on the interaction with colleagues and customers (Column 2), recruiters prefer applicants with more openness to experience, extraversion and agreeableness. For routine and non-routine tasks

\footnotetext{
9 The predicted hiring probabilities for the remaining personality trait attributes are as follows: $36 \%$ for less conscientious applicants versus $54 \%$ for more conscientious applicants, $41 \%$ versus $49 \%$ for less/more emotionally stable applicants, $42 \%$ versus $49 \%$ for less/more open applicants, and $44 \%$ versus $46 \%$ for less/more extroverted applicants.

10 One reason explaining the higher preference of average wages over lower wages is that it prevents conflict costs resulting from firm-level institutions such as works councils, which lobby for equal pay. Furthermore, collective agreements (common for qualified workers) impede paying lower than the bargained wages.
} 
(Columns 3 and 4), we do not find any stronger or weaker preference for professional competence or any of the 'big five' personality traits.

\section{[FIGURE 3]}

Figure 3 depicts the predicted hiring probabilities for job applicants with different personality types with respect to different tasks required by the recruiters. Figure 3 (a) shows that, when the intensity of analytical job tasks is higher, the probability of being hired increases from $44 \%$ to $52 \%$ for more open applicants in comparison to less open applicants. Regarding less versus more conscientiousness, the hiring probability even increases from $49 \%$ to $58 \%$ with higher analytical job task intensity. Figure 3 (b) shows that, when the intensity of interactive job tasks is higher, the probability of being hired increases from $46 \%$ to $51 \%$ for less versus more open applicants, from $43 \%$ to $49 \%$ for less versus more extraverted applicants and from $51 \%$ to even $63 \%$ for less versus more agreeable applicants. This finding is in line with the results by Mount et al. (1998), who found that agreeableness, in particular, is positively related to performance in jobs involving interpersonal interactions. For routine and non-routine job tasks, Figures 3 (c) and (d) show no significant change in the hiring probabilities with increasing task intensity.

\section{Conclusion}

This paper used a discrete choice experiment among recruiters in German firms to determine which personality traits are important for recruiters. We found that all 'big five' personality traits affect the probability of a job applicant being hired by a firm, whereby being conscientious and agreeable have the strongest positive effects. However, the importance of specific personality traits depends on the job tasks for which firms recruit the new hires: for analytical tasks, recruiters particularly value openness to experience and conscientiousness; for interactive tasks, they favour applicants with a high openness to experience, extraversion and agreeableness.

Our results add to the literature on the impact of personality traits on the labour market. Our findings show that recruiters select candidates for certain tasks based on personality traits - most probably because they expect these employees to be more effective in performing such tasks. With respect to interactive tasks, the preference of recruiters for employees with an agreeable personality is in line with the literature, which shows higher performance levels of agreeable employees in jobs with interpersonal interactions (Mount et al., 1998). Along the same lines, 
openness and extraversion seem to be crucial personality traits when jobs imply the interaction with customers and colleagues. Furthermore, the study highlights the importance of both openness to experience and conscientiousness for performing analytical tasks.

However, we may also have expected recruiters to favour certain personality traits, such as a high openness to experience, for performing non-routine tasks. Although our empirical analysis does not support this expectation, one reason for this could be that the concept of 'non-routine' is too heterogeneous and thus needs to be more accurately defined. Further research ought to analyse more specific personality-task matches in this task domain.

Our analysis also has implications for both employers and policy makers. Autor et al. (2003) and Weinberger (2014) showed that routine tasks lose their relevance due to technological change, while analytical and interactive tasks gain importance. Our results suggest that individuals lacking the personality traits that are important for firms recruiting for jobs with analytical and interactive tasks are likely to face increasing disadvantages in the labour market. These shifting labour market demands might not only affect individuals but also society as a whole because noncognitive skills are considered to contribute to the strong inter-generational correlation in labour market outcomes (Mulligan, 1999). Therefore, public policy and firms involved in apprenticeship training should recognise that fostering non-cognitive skills in high school as well as vocational education is an important aspect in adequately preparing individuals for the rapidly changing demands of the labour market. Hoeschler et al. (2018) provided empirical evidence that certain personality traits (in their study conscientiousness, agreeableness and emotional stability) of young adults participating in an apprenticeship training develop more strongly than other traits do. Fields of action should therefore include the curriculum development of training programmes as well as targeted support in the personal development of trainees. 


\section{References}

Alda, H. and Friedrich, A. (2014). Campus-files der BIBB/BAuA-Erwerbstätigenbefragungen 2006 und 2012, BIBB-FDZ Daten- und Methodenberichte 1/2014 Version 3, Bundesinstitut für Berufsbildung, Bonn.

Almlund, M., Duckworth, A. L., Heckman, J. and Kautz, T. (2011). Personality Psychology and Economics, Vol. 4, Elsevier, Amsterdam, chapter 1, pp. 1-181. https://doi.org/10.1016/B9780-444-53444-6.00001-8

Autor, D. H. and Handel, M. J. (2013). Putting Tasks to the Test: Human Capital, Job Tasks, and Wages, Journal of Labor Economics 31(2): S59-S96. https://doi.org/10.1086/669332

Autor, D. H., Levy, F. and Murnane, R. J. (2003). The Skill Content of Recent Technological Change: An Empirical Exploration, Quarterly Journal of Economics 118(4): 1279- 1333. https://doi.org/10.1162/003355303322552801

Biesma, R., Pavlova, M., van Merode, G. and Groot, W. (2007). Using Conjoint Analysis to Estimate Employers Preferences for Key Competencies of Master Level Dutch Graduates Entering the Public Health Field, Economics of Education Review 26(3): 375-386. https://doi.org/10.1016/j.econedurev.2006.01.004

Borghans, L., Duckworth, A. L., Heckman, J. J. and ter Weel, B. (2008). The Economics and Psychology of Personality Traits, Journal of Human Resources 43(4): 972-1059. https://doi.org/10.3368/jhr.43.4.972

Caliendo, M., Fossen, F. and Kritikos, A. S. (2014). Personality Characteristics and the Decisions to Become and Stay Self-employed, Small Business Economics 42(2): 787-814. https://doi.org/10.1007/s11187-013-9514-8

Cameron, A. C. and Trivedi, P. K. (2010). Microeconometrics Using Stata, Stata Press.

Di Stasio, V. (2014). Education as a Signal of Trainability: Results from a Vignette Study with Italian Employers, European Sociological Review 30(6): 796-809. https://doi.org/10.1093/esr/jcu074

Di Stasio, V. and van de Werfhorst, H. G. (2016). Why Does Education Matter to Employers in Different Institutional Contexts? A Vignette Study in England and the Netherlands, Social Forces 95(1): 77-106. https://doi.org/10.1093/sf/sow027

Dunn, W., Mount, M., Barrick, M. and Ones, D. (1995). Relative Importance of Personality and General Mental Ability in Managers' Judgments of Applicant Qualifications, Journal of Applied Psychology 80(4): 500-509. https://doi.org/10.1037/0021-9010.80.4.500

Eriksson, T. and Kristensen, N. (2014). Wages or Fringes? Some Evidence on Trade-Offs and Sorting, Journal of Labor Economics 32(4): 899-928. 
Frosch, K., Harhoff, D., Hoisl, K., Steinle, C. and Zwick, T. (2015). Candidate Screening for the Recruitment of Critical Research and Development Workers - A Report and Preliminary Results with Evidence from Experimental Data from German High-Tech Firms, ZEW DP 15-002. http://dx.doi.org/10.2139/ssrn.2567186

Geel, R., Mure, J. and Backes-Gellner, U. (2011). Specificity of Occupational Training and Occupational Mobility: An Empirical Study Based on Lazears Skill-weights Approach, Education Economics 19(5): 519-535. https://doi.org/10.1080/09645291003726483

Gerhards, C., Mohr, S., Friedrich, A., Troltsch, K. and Christ, A. (2014). BIBB-Qualifizierungspanel 2012, BIBB-FDZ Daten- und Methodenberichte 2/2014 Version 2.1, Bundesinstitut für Berufsbildung, Bonn.

Gosling, S. D., Rentfrow, P. J. and Swann Jr., W. B. (2003). A very brief Measure of the Big-Five Personality Domains, Journal of Research in Personality 37: 504-528. https://doi.org/10.1016/S0092-6566(03)00046-1

Greene, W. H. (2003). Econometric Analysis, 4th edn, Prentice Hall, Upper Saddle River, NJ.

Hainmüller, J., Hangartner, D. and Yamamoto, T. (2015). Validating Vignette and Conjoint Survey Experiments against Real-World Behavior, Proceedings of the National Academy of Science 112(8): 2395-2400. https://doi.org/10.1073/pnas.1416587112

Hensher, D. and Greene, W. H. (2003). The Mixed Logit Model: The State of Practice, Transportation 30(2): 133-176.

Hoeschler, P. and Backes-Gellner, U. (2018). The Relative Importance of Personal Characteristics for the Hiring of Young Workers, Swiss Leading House WP 142.

Hoeschler, P., Balestra, S. and Backes-Gellner, U. (2018). The Development of Non-Cognitive Skills in Adolescence. Economics Letters 163: 40-45. https://doi.org/10.1016/j.econlet.2017.11.012

Hole, A. R. (2015). DCREATE: Stata Module to Create Efficient Designs for Discrete Choice Experiments. Statistical Software Components S458059. Revised 25 Aug 2017.

Humburg, M. and van der Velden, R. (2015). Skills and the Graduate Recruitment Process: Evidence from two Discrete Choice Experiments, Economics of Education Review 49(C): 24-41. https://doi.org/10.1016/j.econedurev.2015.07.001

Jackson, M. (2006). Personality Traits and Occupational Attainment, European Sociological Review 22(2): 187-199. https://doi.org/10.1093/esr/jci051

John, O. P., Donahue, E. M. and Kentle, R. L. (1991). The "Big Five" Inventory - Versions 4a and 54, Institute of Personality and Social Research, Berkeley, University of California.

Lancsar, E., Fiebig, D. G. and Hole, A. R. (2017). Discrete Choice Experiments: A Guide to Model Specification, Estimation and Software, PharmaEconomics 35(7): 697-716. https://doi.org/10.1007/s40273-017-0506-4 
Matthews, G., Deary, I. J. and Whiteman, M. C. (2012). Personality Traits, 3rd edn, Cambridge University Press, Cambridge.

McFadden, D. (1973). Conditional Logit Analysis of Qualitative Choice Behavior, in P. Zarembka (ed.), Frontiers in Econometrics, Academic Press, New York.

Mount, M. K., Barrick, M. R. and Stewart, G. L. (1998). Five-factor Model of Personality and Performance in Jobs Involving Interpersonal Interactions, Human Performance 11(23): 145165. https://doi.org/10.1080/08959285.1998.9668029

Moy, J. W. and Lam, K. F. (2004). Selection Criteria and the Impact of Personality on Getting Hired, Personnel Review 33(5): 521-535. https://doi.org/10.1108/00483480410550134

Mulligan, C. (1999). Galton Versus the Human Capital Approach to Inheritance, Journal of Political Economy 107(6): 184-224. https://doi.org/10.1086/250108

Petzold, K. (2017). The Role of International Student Mobility in Hiring Decisions. A Vignette Experiment Among German Employers, Journal of Education and Work 30(8): 893-911. https://doi.org/10.1080/13639080.2017.1386775

Piopiunik, M., Schwerdt, G., Simon, L. and Woessmann, L. (2020). Skills, Signals, and Employability: An Experimental Investigation, European Economic Review 123: 103374. https://doi.org/10.1016/j.euroecorev.2020.103374

Protsch, P. and Solga, H. (2017). Going Across Europe for an Apprenticeship? A Factorial Survey Experiment on Employers' Hiring Preferences in Germany, Journal of European Social Policy 27(4): 387-399. https://doi.org/10.1177/0958928717719200

Revelt, D. and Train, K. (1998). Mixed Logit with Repeated Choices: Households' Choices of Appliance Efficiency Level, The Review of Economics and Statistics 80(4): 647- 657. https://doi.org/10.1162/003465398557735

Richter, D., Metzing, M., Weinhardt, M. and Schupp, J. (2013). SOEP Scales Manual. SOEP Survey Papers 138: Series C, DIW/SOEP, Berlin.

Schönfeld, Gudrun, Wenzelmann, Felix, Pfeifer, Harald, Risius, Paula, Wehner, Caroline (2020). Training in Germany - an investment to counter the skilled worker shortage. Results of the 2017/18 BIBB Cost-Benefit Survey, BIBB Report 3/2020.

Spitz-Oener, A. (2006). Technical Change, Job Tasks and Rising Educational Demands: Looking Outside the Wage Structure, Journal of Labor Economics 24(2): 235-270. https://doi.org/10.1086/499972

Teijeiro, M., Rungo, P. and Freire, M. J. (2013). Graduate Competencies and Employability: the Impact of Matching Firms' Needs and Personal Attainments, Economics of Education Review 34(C): 286-295. https://doi.org/10.1016/j.econedurev.2013.01.003 
Weinberger, C. J. (2014). The Increasing Complementarity Between Cognitive and Social Skills, The Review of Economics and Statistics 96(5): 849-861. https://doi.org/10.1162/REST_a_00449

Wells, R., Ham, R. and Junankar, P. N. R. (2016). An Examination of Personality in Occupational Outcomes: Antagonistic Managers, Careless Workers and Extraverted Salespeople, Applied Economics 48(7): 636-651. https://doi.org/10.1080/00036846.2015.1085636 


\section{Graphs and Tables}

Figure 1: Example of the Discrete Choice Experiment on Recruiting Decisions

The following is a question on the recruitment of skilled workers. Please imagine the following situation, regardless of whether your company is currently looking for professionals or not:

In your company there is an urgent need to occupy a full-time position in the profession (Prog.: Show selected profession). After reviewing the application documents there are only two people to choose from, of which you will in any case be hiring one.

- Both are 28 years old with German as their mother tongue.

- Both have a good educational degree and five years of relevant professional experience in the initial training firm.

- All other unspecified decision criteria for recruitment, such as gender or additional qualifications, are the same for both professionals.

Based on the personal interview and a trial working day, you have received an impression of the professional competences as well as the personality of the two professionals. This information is presented below. Please indicate if you would hire skilled worker 1 or 2.

\section{Please enter the appropriate number 1 or 2 and then click Return.}

\section{1: Profile Job Applicant 1}

... has average professional competence.

... shows active imagination and solves tasks in an original way.

... completes tasks thoroughly and efficiently.

... seems to be reserved and quiet when dealing with others.

... seems to be considerate and kind to others.

... seems to be tense and nervous.

... receives a wage that equals the average skilled labour wage in your company.

\section{2: Profile Job Applicant 2}

... has above-average professional competence.

... shows little imagination and solves tasks in a conventional way.

... completes tasks carelessly and unorganised.

... seems to be communicative and sociable when dealing with others.

... seems to be sometimes somewhat rude to others.

... seems to be relaxed and to handle stress well.

... receives a wage that is $15 \%$ above the average skilled labour wage in your company. 
Table 1: Descriptive Statistics

\begin{tabular}{lrrrrr}
\hline Variable Names & N & mean & sd & min & max \\
\hline Analytical Tasks & 634 & 3.41 & 1.08 & 1 & 5 \\
Interactive Tasks & 634 & 2.82 & 1.23 & 1 & 5 \\
Routine Tasks & 634 & 3.08 & 1.33 & 1 & 5 \\
Non-Routine Tasks & 634 & 3.71 & 1.07 & 1 & 5 \\
Recruitment: Alone & 634 & 0.27 & 0.45 & 0 & 1 \\
Recruitment: Together & 634 & 0.73 & 0.45 & 0 & 1 \\
Owner & 634 & 0.41 & 0.49 & 0 & 1 \\
CEO & 634 & 0.17 & 0.37 & 0 & 1 \\
Department Head & 634 & 0.10 & 0.30 & 0 & 1 \\
Head HR & 634 & 0.15 & 0.35 & 0 & 1 \\
Head Commerce & 634 & 0.08 & 0.27 & 0 & 1 \\
Head of Training & 634 & 0.03 & 0.17 & 0 & 1 \\
Other Position & 634 & 0.07 & 0.25 & 0 & 1 \\
Male & 634 & 0.62 & 0.49 & 0 & 1 \\
Tenure in Years & 634 & 13.91 & 10.46 & 1 & 50 \\
No Vocational Degree & 634 & 0.00 & 0.04 & 0 & 1 \\
Vocational Degree & 634 & 0.16 & 0.37 & 0 & 1 \\
Higher Voc. Degree & 634 & 0.38 & 0.49 & 0 & 1 \\
Academic Degree & 634 & 0.46 & 0.50 & 0 & 1 \\
\hline
\end{tabular}

Source: BIBB-CBS 2017/2018, own calculations. 
Table 2: Overview of Applicants' Attributes and Values in the Discrete Choice Experiment

Attribute Attribute Values

The applicant...

Professional (1) ... has average professional competence

Competence

(2) ... has above average professional competence

Big Five -

(1) ... shows little imagination and solves tasks in a conventional way

Openness

(2) ... shows active imagination and solves tasks in an original way

Big Five -

(1) ... completes tasks carelessly and unorganised

Conscientiousness (2) ... completes tasks thoroughly and efficiently

Big Five -

(1) ... seems to be reserved and quiet when dealing with others

Extraversion

(2) ... seems to be communicative and sociable when dealing with others

Big Five -

(1) ... seems to be cold and sometimes somewhat rude to others

Agreeableness

(2) ... seems to be considerate and kind to others

Big Five -

(1) ... seems to be tense and nervous

Emotional Stability (2) ... seems to be relaxed and to handle stress well

Gross Wage (1) ... receives a wage that is $15 \%$ above the company's average skilled labour wage

(2) ... receives a wage that is $10 \%$ above the company's average skilled labour wage

(3) ... receives a wage that is $5 \%$ above the company's average skilled labour wage

(4) ... receives a wage that equals the company's average skilled labour wage

(5) ... receives a wage that is $5 \%$ below the company's average skilled labour wage

(6) ... receives a wage that is $10 \%$ below the company's average skilled labour wage

(7) ... receives a wage that is $15 \%$ below the company's average skilled labour wage 
Figure 2: Marginal Effects: Competence and Personality

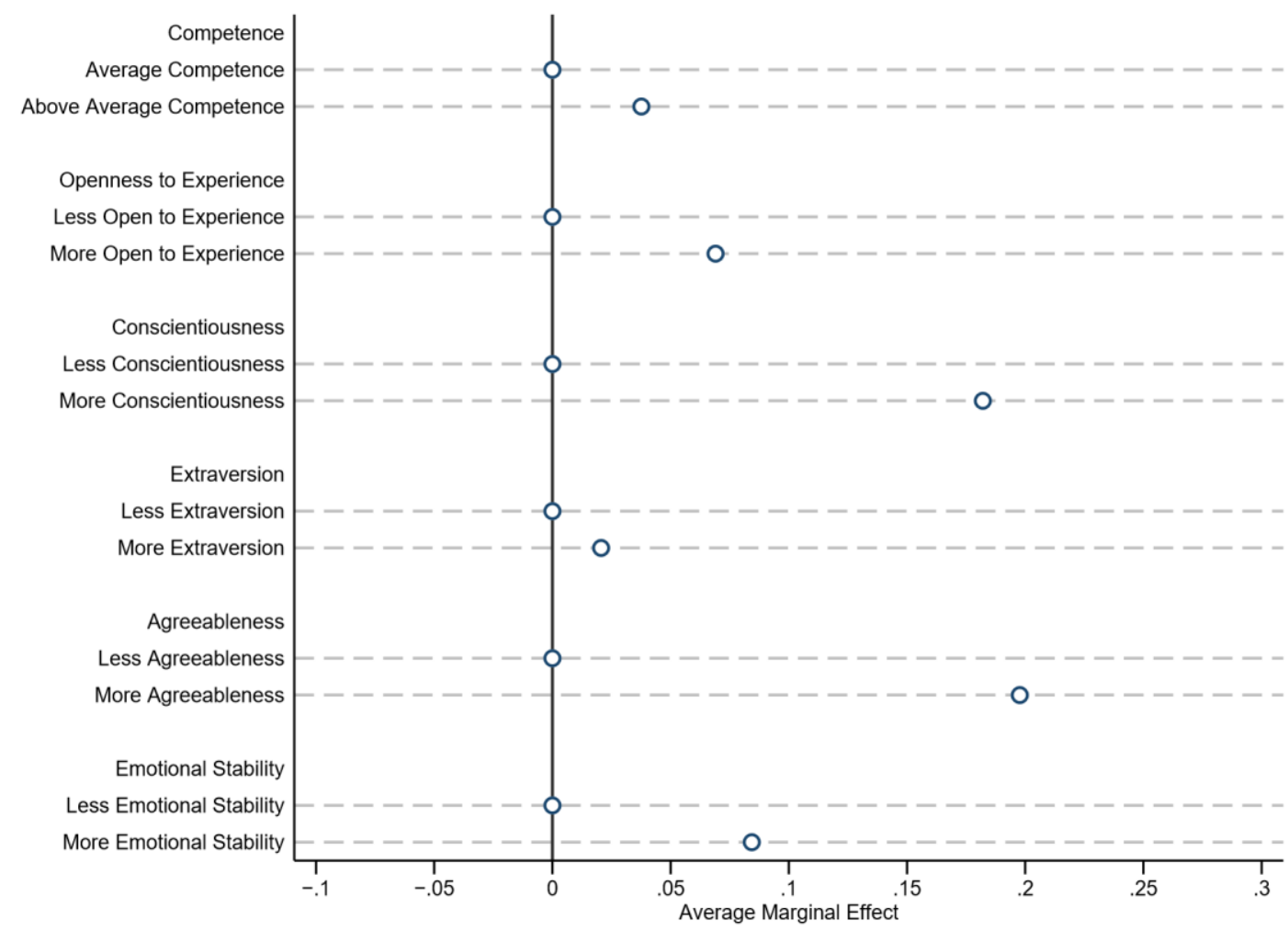

Source: BIBB-CBS 2017/2018, own calculations.

Note: The marginal effects are based on the mixed logit model specification presented in Table A3. 
Figure 3: Interaction Effect between Personality Traits and Tasks

(a) Analytical Tasks

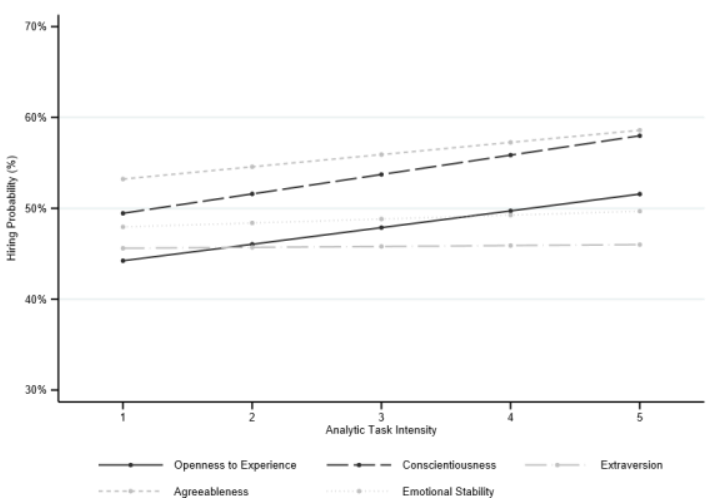

(c) Routine Tasks

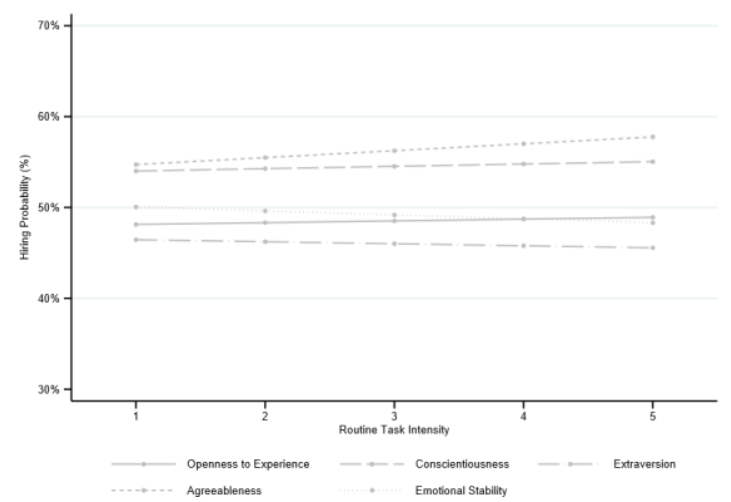

(b) Interactive Tasks

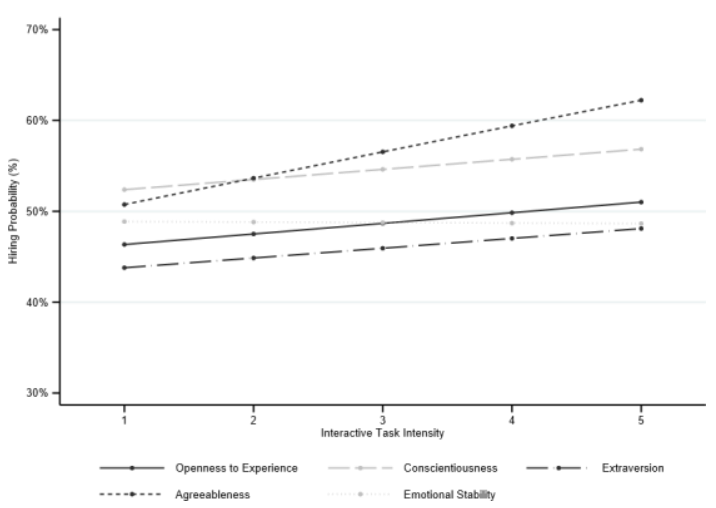

(d) Non-Routine Tasks

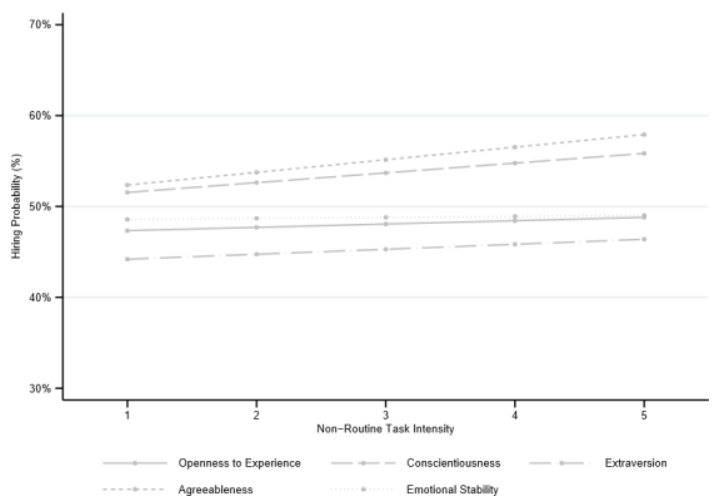

Source: BIBB-CBS 2017/2018, own calculations.

Note: The predicted probabilities are based on the mixed logit model specification presented in Table A4. The significant interaction terms are marked in black, while the insignificant ones are in grey. 


\section{A Appendix}

Table A1: Proportional frequencies of attribute values in worker profiles and choices made

\begin{tabular}{lcc}
\hline & Worker profiles & Choices made \\
Variable names & mean & mean \\
\hline Average Competencies & 0.50 & 0.50 \\
Above Average Competencies & 0.50 & 0.50 \\
Less Open to Experience & 0.50 & 0.43 \\
More Open to Experience & 0.50 & 0.57 \\
Less Conscientiousness & 0.50 & 0.30 \\
More Conscientiousness & 0.50 & 0.70 \\
Less Extraversion & 0.50 & 0.47 \\
More Extraversion & 0.50 & 0.53 \\
Less Agreeableness & 0.50 & 0.28 \\
More Agreeableness & 0.50 & 0.72 \\
Less Emotional Stability & 0.50 & 0.43 \\
More Emotional Stability & 0.50 & 0.57 \\
15 Percent Above Average Wage & 0.15 & 0.13 \\
10 Percent Above Average Wage & 0.14 & 0.14 \\
5 Percent Above Average Wage & 0.14 & 0.14 \\
Average Wage & 0.14 & 0.16 \\
5 Percent Below Average Wage & 0.14 & 0.14 \\
10 Percent Below Average Wage & 0.15 & 0.15 \\
15 Percent Below Average Wage & 0.14 & 0.14 \\
\hline N & 8,342 & 4,171 \\
\hline
\end{tabular}

Source: BIBB-CBS 2017/2018, own calculations. 
Table A2: Comparison of job and firm characteristics of recruiters' sample with representative full BIBB-CBS sample

\begin{tabular}{|c|c|c|c|c|c|c|c|c|c|c|c|}
\hline \multirow[b]{2}{*}{ Variable Names } & \multirow[b]{2}{*}{$\mathbf{N}$} & \multicolumn{3}{|c|}{ Recruiters' Sample } & \multicolumn{6}{|c|}{ Full BIBB-CBS Sample } & \multirow[b]{2}{*}{ p-value } \\
\hline & & mean & sd & $\min$ & $\max$ & $\mathbf{N}$ & mean & sd & $\min$ & $\max$ & \\
\hline \multicolumn{12}{|l|}{ Task Structure } \\
\hline Analytical Tasks & 634 & 3,41 & 1,08 & 1 & 5 & 2844 & 3,44 & 1,09 & 1 & 5 & 0,52 \\
\hline Interactive Tasks & 634 & 2,82 & 1,23 & 1 & 5 & 2828 & 2,75 & 1,19 & 1 & 5 & 0,16 \\
\hline Routine Tasks & 634 & 3,08 & 1,33 & 1 & 5 & 2813 & 3,09 & 1,28 & 1 & 5 & 0,79 \\
\hline Non-Routine Tasks & 634 & 3,71 & 1,07 & 1 & 5 & 2839 & 3,71 & 1,04 & 1 & 5 & 0,94 \\
\hline \multicolumn{12}{|l|}{ Firm Size } \\
\hline 1-9 Employees & 634 & 0,32 & 0,47 & 0 & 1 & 4039 & 0,33 & 0,47 & 0 & 1 & 0,45 \\
\hline 10-49 Employees & 634 & 0,41 & 0,49 & 0 & 1 & 4039 & 0,36 & 0,48 & 0 & 1 & 0,01 \\
\hline 50-499 Employees & 634 & 0,24 & 0,43 & 0 & 1 & 4039 & 0,25 & 0,44 & 0 & 1 & 0,50 \\
\hline > 499 Employees & 634 & 0,03 & 0,18 & 0 & 1 & 4039 & 0,06 & 0,24 & 0 & 1 & 0,00 \\
\hline Voc. Train. Provider & 634 & 0,74 & 0,44 & 0 & 1 & 4045 & 0,75 & 0,43 & 0 & 1 & 0,37 \\
\hline Public Sector & 634 & 0,07 & 0,26 & 0 & 1 & 4045 & 0,10 & 0,30 & 0 & 1 & 0,01 \\
\hline Last Recruit. Year & 634 & 2018 & 1,08 & 2015 & 2019 & 3535 & 2016 & 5,00 & 1950 & 2019 & 0,00 \\
\hline \multicolumn{12}{|l|}{ Branch } \\
\hline Agriculture (A) & 634 & 0,01 & 0,12 & 0 & 1 & 4045 & 0,02 & 0,15 & 0 & 1 & 0,10 \\
\hline Manufacturing (C) & 634 & 0,09 & 0,28 & 0 & 1 & 4045 & 0,09 & 0,28 & 0 & 1 & 0,94 \\
\hline Electricity (D) & 634 & 0,01 & 0,10 & 0 & 1 & 4045 & 0,01 & 0,09 & 0 & 1 & 0,83 \\
\hline Water Supply (E) & 634 & 0,01 & 0,09 & 0 & 1 & 4045 & 0,01 & 0,09 & 0 & 1 & 0,95 \\
\hline Construction (F) & 634 & 0,10 & 0,30 & 0 & 1 & 4045 & 0,09 & 0,28 & 0 & 1 & 0,35 \\
\hline Retail, Wholesale (G) & 634 & 0,20 & 0,40 & 0 & 1 & 4045 & 0,16 & 0,36 & 0 & 1 & 0,01 \\
\hline Transportation $(\mathrm{H})$ & 634 & 0,04 & 0,19 & 0 & 1 & 4045 & 0,03 & 0,17 & 0 & 1 & 0,41 \\
\hline Accommodation (I) & 634 & 0,07 & 0,25 & 0 & 1 & 4045 & 0,06 & 0,24 & 0 & 1 & 0,41 \\
\hline Information Act. (J) & 634 & 0,04 & 0,19 & 0 & 1 & 4045 & 0,04 & 0,19 & 0 & 1 & 0,97 \\
\hline Finance, Insurance (K) & 634 & 0,02 & 0,14 & 0 & 1 & 4045 & 0,03 & 0,16 & 0 & 1 & 0,19 \\
\hline Real Estate (L) & 634 & 0,02 & 0,13 & 0 & 1 & 4045 & 0,02 & 0,14 & 0 & 1 & 0,71 \\
\hline Professional Act. (M) & 634 & 0,07 & 0,26 & 0 & 1 & 4045 & 0,08 & 0,27 & 0 & 1 & 0,44 \\
\hline Administrat. Act. (N) & 634 & 0,07 & 0,25 & 0 & 1 & 4045 & 0,06 & 0,24 & 0 & 1 & 0,52 \\
\hline Public Admin. (O) & 634 & 0,03 & 0,16 & 0 & 1 & 4045 & 0,04 & 0,19 & 0 & 1 & 0,13 \\
\hline Education (P) & 634 & 0,01 & 0,10 & 0 & 1 & 4045 & 0,02 & 0,12 & 0 & 1 & 0,13 \\
\hline Health, Social (Q) & 634 & 0,09 & 0,29 & 0 & 1 & 4045 & 0,10 & 0,31 & 0 & 1 & 0,21 \\
\hline Arts, Recreation (R) & 634 & 0,00 & 0,07 & 0 & 1 & 4045 & 0,01 & 0,08 & 0 & 1 & 0,37 \\
\hline Other Services (S) & 634 & 0,06 & 0,23 & 0 & 1 & 4045 & 0,06 & 0,24 & 0 & 1 & 0,73 \\
\hline
\end{tabular}

Source: BIBB-CBS 2017/2018, own calculations. 
Table A3: Regression Models: Basic Specification for Recruitment Decisions

\begin{tabular}{|c|c|c|c|}
\hline & $\begin{array}{c}\text { Conditional } \\
\text { Logit }\end{array}$ & $\begin{array}{l}\text { Mixed Logit } \\
\text { MEAN }\end{array}$ & SD \\
\hline \multicolumn{4}{|c|}{ Personal Attributes } \\
\hline Above Average Competence & $0.253^{* * *}$ & $0.341 * * *$ & $-0.387^{* *}$ \\
\hline (Ref. Average Competence) & $(0.043)$ & $(0.059)$ & $(0.141)$ \\
\hline More Open to Experience & $0.447^{* * *}$ & $0.625^{* * *}$ & $0.509 * * *$ \\
\hline (Ref. Less Open to Experience) & $(0.046)$ & $(0.067)$ & $(0.132)$ \\
\hline More Conscientiousness & $1.114^{* * *}$ & $1.569 * * *$ & $0.844 * * *$ \\
\hline (Ref. Less Conscientiousness) & $(0.054)$ & $(0.100)$ & $(0.100)$ \\
\hline More Extraversion & $0.133^{* * *}$ & $0.196 * * *$ & -0.187 \\
\hline (Ref. Less Extraversion) & $(0.040)$ & $(0.055)$ & $(0.193)$ \\
\hline More Agreeableness & $1.109 * * *$ & $1.581 * * *$ & $1.100 * * *$ \\
\hline (Ref. Less Agreeableness) & $(0.055)$ & $(0.100)$ & $(0.098)$ \\
\hline More Emotional Stability & $0.538 * * *$ & $0.764 * * *$ & $0.644 * * *$ \\
\hline (Ref. Less Emotional Stability) & $(0.047)$ & $(0.072)$ & $(0.107)$ \\
\hline \multicolumn{4}{|c|}{ Wage Attributes: Ref. Average Wage } \\
\hline \multirow[t]{2}{*}{15 Percent Above Average Wage } & $-0.600 * * *$ & $-0.777^{* * *}$ & \\
\hline & $(0.104)$ & $(0.145)$ & \\
\hline \multirow[t]{2}{*}{10 Percent Above Average Wage } & $-0.309 * *$ & $-0.319 *$ & \\
\hline & $(0.110)$ & $(0.151)$ & \\
\hline \multirow[t]{2}{*}{5 Percent Above Average Wage } & $-0.200 *$ & -0.252 & \\
\hline & $(0.096)$ & $(0.134)$ & \\
\hline \multirow[t]{2}{*}{5 Percent Below Average Wage } & $-0.252^{* *}$ & $-0.269 *$ & \\
\hline & $(0.097)$ & $(0.131)$ & \\
\hline \multirow[t]{2}{*}{10 Percent Below Average Wage } & -0.186 & -0.195 & \\
\hline & $(0.110)$ & (0.149) & \\
\hline \multirow[t]{2}{*}{15 Percent Below Average Wage } & $-0.314 * *$ & $-0.419 * *$ & \\
\hline & $(0.110)$ & (0.149) & \\
\hline Observations; N & $8342 ; 634$ & & $8342 ; 634$ \\
\hline Log-likelihood & -1960 & & -1877 \\
\hline
\end{tabular}

Source: BIBB-CBS 2017/2018, own calculations.

Note: Standard errors in parentheses; ${ }^{*} p<0.05,{ }^{* *} p<0.01, * * * p<0.001$. Maximum likelihood with clustered standard errors based on 300 Halton draws. 
Table A4: Recruitment Decisions and Skilled Worker's Tasks

\begin{tabular}{|c|c|c|c|c|}
\hline & Analytical & Interactive & Routine & Non-Routine \\
\hline \multicolumn{5}{|l|}{ MEAN } \\
\hline \multicolumn{5}{|l|}{ Personal Attributes } \\
\hline Above Average Competence & 0.347 & $0.484 * * *$ & $0.407 * *$ & $0.446 *$ \\
\hline (Ref. Average Competence) & $(0.196)$ & $(0.144)$ & $(0.144)$ & $(0.204)$ \\
\hline More Open to Experience & 0.082 & $0.348^{*}$ & $0.571^{* * *}$ & $0.510^{*}$ \\
\hline (Ref. Less Open to Experience) & $(0.196)$ & $(0.152)$ & $(0.148)$ & $(0.218)$ \\
\hline More Conscientiousness & $0.994 * * *$ & $1.333^{* * *}$ & $1.507^{* * *}$ & $1.258^{* * *}$ \\
\hline (Ref. Less Conscientiousness) & $(0.241)$ & $(0.188)$ & $(0.191)$ & $(0.267)$ \\
\hline More Extraversion & 0.169 & -0.060 & $0.258 *$ & 0.017 \\
\hline (Ref. Less Extraversion) & $(0.181)$ & $(0.135)$ & $(0.130)$ & $(0.194)$ \\
\hline More Agreeableness & $1.239 * * *$ & $0.964 * * *$ & $1.400 * * *$ & $1.191 * * *$ \\
\hline (Ref. Less Agreeableness) & $(0.226)$ & $(0.180)$ & (0.189) & $(0.259)$ \\
\hline More Emotional Stability & $0.636^{* *}$ & $0.777^{* * *}$ & $0.876^{* * *}$ & $0.729 * *$ \\
\hline (Ref. Less Emotional Stability) & $(0.207)$ & (0.159) & $(0.166)$ & $(0.238)$ \\
\hline \multicolumn{5}{|c|}{ Interaction between Personal Attributes and Tasks (for each Task see Column Title) } \\
\hline \multirow[t]{2}{*}{ Above Average Competence $\times$ Task } & -0.001 & -0.051 & -0.022 & 0.028 \\
\hline & $(0.057)$ & $(0.049)$ & $(0.043)$ & $(0.053)$ \\
\hline \multirow[t]{2}{*}{ More Open to Experience $\times$ Task } & $0.163^{* *}$ & $0.103^{*}$ & 0.017 & 0.032 \\
\hline & $(0.056)$ & $(0.051)$ & $(0.045)$ & $(0.058)$ \\
\hline \multirow[t]{2}{*}{ More Conscientiousness $\times$ Task } & $0.173 * *$ & 0.089 & 0.021 & 0.086 \\
\hline & $(0.065)$ & $(0.060)$ & $(0.051)$ & $(0.069)$ \\
\hline \multirow[t]{2}{*}{ More Extraversion $\times$ Task } & 0.009 & $0.097^{*}$ & -0.020 & 0.049 \\
\hline & $(0.051)$ & $(0.046)$ & $(0.038)$ & $(0.052)$ \\
\hline \multirow[t]{2}{*}{ More Agreeableness $\times$ Task } & 0.104 & $0.224 * * *$ & 0.058 & 0.107 \\
\hline & $(0.062)$ & $(0.061)$ & $(0.054)$ & $(0.068)$ \\
\hline \multirow[t]{2}{*}{ More Emotional Stability $\times$ Task } & 0.038 & -0.005 & -0.038 & 0.010 \\
\hline & $(0.058)$ & $(0.052)$ & $(0.047)$ & $(0.061)$ \\
\hline
\end{tabular}

Wage Attributes: Ref. Average Wage 


\begin{tabular}{|c|c|c|c|c|}
\hline & Analytical & Interactive & Routine & Non-Routine \\
\hline \multicolumn{5}{|l|}{ MEAN } \\
\hline \multirow[t]{2}{*}{15 Percent above Average Wage } & $-0.766 * * *$ & $-0.767 * * *$ & $-0.776 * * *$ & $-0.771 * * *$ \\
\hline & $(0.145)$ & $(0.144)$ & $(0.146)$ & $(0.145)$ \\
\hline \multirow[t]{2}{*}{10 Percent above Average Wage } & $-0.311^{*}$ & $-0.313^{*}$ & $-0.322 *$ & $-0.315 *$ \\
\hline & $(0.150)$ & $(0.150)$ & $(0.151)$ & $(0.151)$ \\
\hline \multirow[t]{2}{*}{5 Percent above Average Wage } & -0.240 & -0.241 & -0.248 & -0.249 \\
\hline & $(0.134)$ & $(0.133)$ & $(0.134)$ & $(0.134)$ \\
\hline \multirow[t]{2}{*}{5 Percent below Average Wage } & $-0.269 *$ & $-0.266^{*}$ & $-0.268^{*}$ & $-0.266^{*}$ \\
\hline & $(0.131)$ & $(0.131)$ & $(0.130)$ & $(0.131)$ \\
\hline \multirow[t]{2}{*}{10 Percent below Average Wage } & -0.178 & -0.194 & -0.197 & -0.190 \\
\hline & $(0.148)$ & $(0.148)$ & (0.149) & $(0.149)$ \\
\hline \multirow[t]{2}{*}{15 Percent below Average Wage } & $-0.405^{* *}$ & $-0.403 * *$ & $-0.421 * *$ & $-0.415^{* *}$ \\
\hline & $(0.148)$ & $(0.148)$ & $(0.148)$ & $(0.148)$ \\
\hline \multicolumn{5}{|l|}{ SD } \\
\hline \multirow[t]{2}{*}{ Above Average Competence } & $-0.406 * *$ & $-0.400 * *$ & $-0.377 * *$ & $-0.389 * *$ \\
\hline & $(0.137)$ & $(0.130)$ & $(0.144)$ & $(0.136)$ \\
\hline \multirow[t]{2}{*}{ More Open to Experience } & $0.490 * * *$ & $0.495^{* * *}$ & $0.508 * * *$ & $0.510 * * *$ \\
\hline & $(0.133)$ & $(0.128)$ & $(0.131)$ & $(0.129)$ \\
\hline \multirow[t]{2}{*}{ More Conscientiousness } & $0.831^{* * *}$ & $0.833^{* * *}$ & $0.845^{* * *}$ & $0.848 * * *$ \\
\hline & $(0.099)$ & $(0.101)$ & $(0.100)$ & $(0.100)$ \\
\hline \multirow[t]{2}{*}{ More Extraversion } & -0.182 & -0.209 & -0.178 & -0.180 \\
\hline & $(0.196)$ & $(0.165)$ & $(0.211)$ & $(0.186)$ \\
\hline \multirow[t]{2}{*}{ More Agreeableness } & $1.103^{* * *}$ & $1.063 * * *$ & $1.094^{* * *}$ & $1.100 * * *$ \\
\hline & (0.099) & $(0.100)$ & $(0.098)$ & $(0.098)$ \\
\hline \multirow[t]{2}{*}{ More Emotional Stability } & $0.636 * * *$ & $0.636 * * *$ & $0.640 * * *$ & $0.636 * * *$ \\
\hline & $(0.108)$ & $(0.105)$ & (0.107) & $(0.108)$ \\
\hline Observations; N & \multicolumn{4}{|c|}{$8342 ; 634$} \\
\hline Log-likelihood & -1869 & -1864 & -1875 & -1874 \\
\hline
\end{tabular}

Source: BIBB-CBS 2017/2018, own calculations.

Note: Standard errors in parentheses; ${ }^{*} p<0.05,{ }^{* *} p<0.01,{ }^{* * *} p<0.001$. Maximum likelihood with clustered standard errors based on 300 Halton draws. 